\title{
MAKNA SIMBOLIK SAWAH DI MASYARAKAT PEDESAAN TINJAUAN KOMUNIKASI LINGKUNGAN PADA MASYARAKAT SEMENDE DARAT TENGAH KABUPATEN MUARA ENIM-SUMATERA SELATAN
}

\author{
Yenrizal \\ Fakultas Dakwah dan Komunikasi UIN Raden Fatah Palembang \\ Email : yen_rizal@yahoo.com \\ Agus Rahmat dan Atwar Bajari \\ Fakultas Ilmu Komunikasi Universitas Padjadjaran \\ Johan Iskandar \\ Fakultas Matematika dan Ilmu Pengetahuan Alam Universitas Padjadjaran
}

\begin{abstract}
Rice fields are an integral part in the life of rural communities, especially in the public of Semende Darat Tengah, Muara Enim, South Sumatra. Rice fields are considered as part of the socio-cultural and economic of society. All of this is part of the communication process conducted by the public environment, particularly the ability to understand the phenomenon of the local environment and then give the meaning to the phenomenon. This is the focus of this study, environmental communication process of society by looking paddy fields as a major agricultural. Through communication ethnoecology approach, this research shown that the people has made the construction process of the rice fields, which are then considered to have a special meaning, ie the meaning of prosperous, the meaning of power, and the meaning of identity. All of not happen by itself, but a process of community communication to understand their natural environment, in particular the existence of paddy. There are a symbolic construction mechanism which lasts from various groups in society.
\end{abstract}

Keyword: Communications; Environmental; Paddy Fields.

\section{ABSTRAK}

Sawah adalah bagian integral dalam kehidupan masyarakat pedesaan, khususnya pada masyarakat Semende Darat Tengah, Kabupaten Muara Enim, Sumatera Selatan. Sawah dianggap sebagai bagian dari tatanan sosial budaya dan ekonomi masyarakat. Semua ini adalah bagian dari proses komunikasi lingkungan yang dilakukan masyarakat, terutama kemampuan memahami fenomena lingkungan setempat dan kemudian memberikan pemaknaan terhadap fenomena tersebut. Penelitian ini memfokuskan pada wilayah tersebut yaitu, proses komunikasi lingkungan masyarakat dalam 
memandang sawah sebagai pertanian utama. Melalui pendekatan etnoekologi komunikasi, penelitian ini menunjukkan bahwa masyarakat melakukan proses konstruksi simbol tersendiri terhadap sawah, yang kemudian dianggap punya makna tersendiri, yaitu makna kesejahteraan, makna kekuasaan, dan makna identitas. Semua makna-makna tersebut tidaklah terjadi dengan sendirinya, namun sebuah proses komunikasi masyarakat dalam memaknai lingkungan alamnya, khususnya eksistensi sawah. Terdapat mekanismekonstruksi simbolikyang berlangsung dari berbagai kelompok di masyarakat.

Kata Kunci: komunikasi; Lingkungan; Sawah.

\section{PENGANTAR}

Karakteristik masyarakat pedesaan selalu diidentikkan dengan lahan pertanian. Pendapat dari Marzali (2012) menegaskan bahwa komunitas pedesaan memang tidak dapat dilepaskan dari kegiatan terhadap lahan pertanian, bahkan hal tersebut dijadikan sebagai strategi untuk mengatasi persoalan-persoalan hidup yang mereka alami, seperti masalah kemiskinan. Marzali (2012:56) kemudian membuat konsep "petani pedesaan" yang disebutnya sebagai "peisan", didasarkan acuan pada Redfield (1956) tentang konsep peasant.

Salah satu aktivitas pertanian masyarakat pedesaan adalah kegiatan bersawah. Sawah merupakan sebuah sejarah panjang kehidupan masyarakat karena sumber produksi makanan pokok manusia, khususnya di Indonesia. Penelitian dari Boomgard (2003) dan Panuju (2013), menunjukkan bahwa padi sebagai tanaman utama pada persawahan merupakan mata rantai utama dalam kehidupan masyarakat dan telah dikembangkan sejak manusia mengenal pertanian. Hal ini bahkan muncul dalam berbagai cerita rakyat dan legenda yang menunjukkan sejarah masyarakat terikat dengan sejarah sawah itu sendiri.

Dalam aktivitas masyarakat bersawah, tampak pula berbagai mekanisme yang dilakukan sebagai bentuk keterikatan masyarakat terhadap lingkungan. Lahan sawah dianggap sebagai bagian integral dari sistem lingkungan yang ada, yang memperlihatkan keterkaitan erat antara masyarakat dan sawah sebagai sistem ekologi. Hasil penelitian beberapa ahli, umumnya bidang Antropologi, Pertanian, dan Lingkungan, seperti Rambo (1984), Dove (2005), Iskandar (2012), dan Soemarwoto (2008) menunjukkan hal ini secara kuat. Dalam bahasa Rambo (1984:47), disebut sebagai aliran energi, materi, dan informasi antara manusia dengan lingkungannya. Sebagai perbandingan dapat dilihat perluasan gagasan ini pada tulisan Florr (2004) dan Iskandar (2012), yang menunjukkan bahwa sawah punya makna simbolik tersendiri, lebih luas lagi sawah sebagai salah satu varian dari lingkungan alam.

Pemaknaan simbolik manusia mengenai lingkungannya merupakan titik tekan utama dalam keilmuan komunikasi, terutama komunikasi lingkungan. Beberapa aksioma tentang komunikasi lingkungan ini dapat dilihat dari gagasan Jurin (2010:3-4) yaitu (a) komunikasi adalah aktivitas manusia, (b) manusia selalu ingin dapat berkomunikasi, (c) pemahaman adalah sasaran komunikasi, (d) tanggungjawab terletak pada komunikator, (e) manusia bergantung pada alam untuk bertahan hidup, (f) bumi/alam memiliki pesannya sendiri untuk dibagikan pada manusia.

Pendapat Jurin tersebut, terutama huruf e dan $\mathrm{f}$ bahwa posisi manusia dan lingkungan ada pada satu mata rantai hubungan yang tidak dapat dipisahkan. Penelitian ini memfokuskan pada aspek tersebut, yaitu bagaimana masyarakat pedesaan melakukan proses konstruksi makna terhadap sawah, yang dianggap sebagai bagian integral dari ekosistem kehidupan mereka. Pendekatan etnoekologi komunikasi sengaja digunakan karena sangat membantu dalam menguraikan keterkaitan manusia dengan lingkungan.

Melalui metode kualitatif, dengan pendekatan etnoekologi komunikasi, penelitian ini telah mewancarai 10 orang narasumber dan dilakukan proses pengamatan berperan serta (participant observation) selama sekitar 11 bulan di lokasi penelitian yaitu, Desa Swarna Dwipe, dan 
Desa Tenam Bungkuk di Semende Darat Tengah, Kabupaten Muara Enim, Sumatera Selatan. Pemilihan desa-desa tersebut dilakukan secara acak dengan pertimbangan memiliki karakteristik sedikit berbeda, yaitu Desa Swarna Dwipe merupakan desa baru hasil pemekaran (2007), sementara Desa Tenam Bungkuk merupakan desa lama yang umumnya menjadi daerah asal warga desa lain di Semende. Kendati demikian, sebenarnya desa manapun di Semende Darat Tengah memiliki karakteristik yang sama, karena mereka satu etnis yang sama, satu keturunan, dan topografi alam yang sama.

Etnisyang samainiadalahetnis Semende, yang berasal dari satu keturunan puyang (nenek moyang) yang diyakini masyarakat dengan sebutan Puyang Awak atau Syekh Nurqadim yang pertama kali membuka daerah ini. Tokoh inilah yang juga dianggap sebagai peletak dasar adat Semende, hingga menyebar ke daerah lain sesuai perpindahan masyarakat berikutnya (Rauf, 2002, Santun, 2010). Sementara kesamaan topografi alam, tampak dari kondisi daerah berada di dataran tinggi, berbukit-bukit, dikelilingi oleh Bukit Putih Embun, Bukit Balai, dan Bukit Barisan, serta dialiri oleh aliran sungai utama yaitu Aiek (Sungai) Talang Kiaghe. Kondisi ini berdampak pada cuaca dingin dan sejuk yang terasa di semua daerah Semende Darat Tengah, serta berimplikasi pada kesamaan jenis tanaman yang dilakukan masyarakat (padi dan kopi sebagai tanaman utama).

Kondisi tersebut, menjadi alasan penting pelaksanaan penelitian ini, yang selanjutnya guna keutuhan penjelasan dan fokus pembahasan didasarkan pada teori interaksionisme simbolik (Blummer, 1986), yang menekankan pada terjadinya proses pemaknaan simbol-simbol oleh manusia. Ini untuk menunjukkan bagaimana tindakan simbolik tersebut terjadi di masyarakat pedesaan dalam sawah, khususnya di wilayah penelitian ini.

\section{PEMBAHASAN}

Proses konstruksi makna atau pemaknaan terhadap sesuatu adalah hal terpenting dalam kegiatan interaksi manusia. Manusia akan selalu menciptakan makna terhadap simbol-simbol tertentu karena pemaknaan adalah hal yang intrinsik sebagai sebuah pikiran kealamiahan dari kehidupan manusia. Blumer (1986) menegaskan bahwa teori interaksionisme simbolik menegaskan tiga premis utama dalam teorinya, yaitu (1) kehidupan manusia didasarkan pada maknamakna yang dirasakan untuk kehidupan mereka, (2) pemaknaan dari beberapa hal datang dan muncul dari interaksi sosial satu sama lainnya, (3) pemaknaan sangat ditentukan oleh proses interpretasi seseorang yang sepakat dengan pemikiran yang menghampirinya.

Pendapat dari Blumer, yang diilhami dari Mead, menunjukkan bahwa maknamakna ditentukan oleh manusia itu sendiri. Mulyana (2002) menyoroti dalam segi bahasa bahwa makna bersifat sembarang, tergantung bagaimana manusia dan masyarakat tersebut memaknainya. Untuk itu, terjadilah proses komunikasi yang intens sehingga simbolsimbol dari lingkungan alam dapat dimaknai dan memiliki arti tersendiri.

Hasil penelitian ini menunjukkan bahwa pemaknaan terhadap sawah di masyarakat Semende Darat Tengah merupakan sebuah proses komunikasi lingkungan yang terjadi dari berbagai mekanisme. Hubungan antara berbagai pihak dan eksistensi lingkungan setempat, menjadi sumber pemaknaan tersendiri yang memunculkan makna-makna khusus bagi sawah. Penjelasan berikut ini menjabarkan makna-makna sawah di masyarakat Semende, khususnya di Semende Darat Tengah.

Sistem persawahan di Semende Darat Tengah masih melakukan mekanisme yang sudah dilakukan sejak zaman nenek moyang mereka dahulu. Sistemnya adalah satu kali setahun (padi usia delapan bulan), menggunakan bibit lokal, pengairan dengan sistem irigasi, dan belum mengenal pupuk kimia secara massif. Sesuai pola ini, maka waktu tenggang bersawah relatif singkat, dan tidak mengenal masa pemberaan, sebagaimana pada padi ladang. Mekanisme 
ini terkait sekali dengan kondisi iklim dan topografi daerah, di mana daerah Semende Darat Tengah berada di wilayah dataran tinggi Bukit Barisan dengan suhu udara berkisar $22^{\circ}-24^{\circ} \mathrm{C}$. Curah hujan merata setiap bulan, dengan sedikit pengecualian pada bulan Juni, Juli, dan Oktober. Data BMKG Sumsel tahun 2013 menunjukkan bahwa curah hujan di bulan tersebut cenderung sedikit dibanding bulan lainnya.

Di masyarakat Semende Darat Tengah, hampir semua desa memiliki areal persawahan, walaupun tidak semua kepala keluarga yang memilikinya. Untuk Desa Swarna Dwipe terdapat sekitar 18 Ha lahan sawah yang dikelola oleh 19 KK. Setiap KK rata-rata memiliki lahan seluas $3 / 4$ Ha. Sementara untuk Desa Tenam Bungkuk, jumlahnya lebih luas lagi, yaitu mencapai $145 \mathrm{Ha}$, dengan luas kepemilikan tiap KK juga berkisar $3 / 4$ Ha. Kondisi ini disesuaikan dengan karakteristik lingkungan alam, serta mekanisme adat yang digunakan. Kondisi alam di Desa Tenam Bunguk tidak memungkinkan untuk membuat persawahan dalam jumlah yang luas karena sedikitnya daerah dataran serta telah lebih dulunya masyarakat menanam kopi. Hal ini tidak lepas dari sejarah awal masyarakat mendiami wilayah ini adalah untuk membuka areal perkebunan baru. Perkembangan berikut yang membuat mereka juga mengusahakan sawah. Sebaliknya di Tenam Bungkuk, sebagai desa lama, memang sudah dari dulu masyarakat mengusahakan persawahan, baru kemudian dikembangkan kebun kopi.

Kendati memiliki perbedaan dari sisi jumlah lahan, tetapi karakteristik dan metode dalam persawahan pada Desa Swarna Dwipe dan Desa Tenam Bungkuk, dapat dikatakan sama. Kesamaan latar belakang etnis, topografi alam, cuaca, dan curah hujan, menyebabkan mereka melakukan metode dan pola yang sama dalam mengolah sawah. Gambaran tentang Desa Swarna Dwipe dan Desa Tenam Bungkuk, dapat dilihat pada gambar berikut.
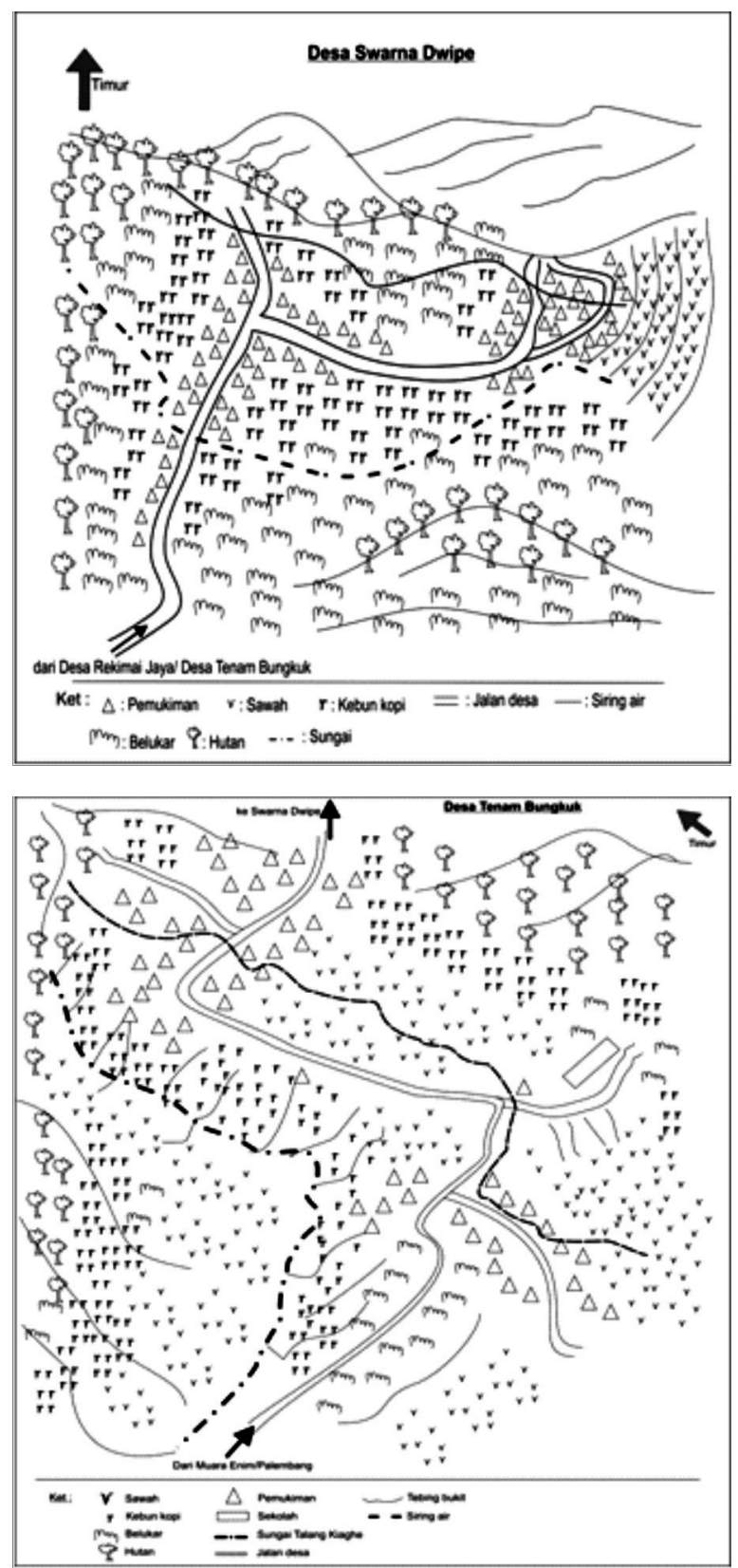

Gambar 1

Desa Swarna Dwipe (atas) dan Desa Tenam Bungkuk (bawah)

Gambaran di atas menunjukkan tata ruang wilayah desa, yang dibagi atas daerah pemukiman, persawahan, kebun kopi, hutan, dan aliran air. Kedua desa memiliki posisi yang sama dalam menempatkan sawah, yaitu berada di daerah landai, utamanya di bawah kebun kopi.

Aspek penting dalam persawahan di Semende Darat Tengah adalah penggunaan 
bibit, di mana terdapat dua varian bibit yang semuanya bersumber dari tanaman padi lokal. Bibit yang lazim digunakan, dalam bahasa setempat di sebut padi jambat teghas dan padi karet. Usianya berkisar tujuh sampai delapan bulan sejak mulai masa nguni (membenih). Jenis ini tetap digunakan masyarakat, tidak ada yang merubahnya dengan jenis bibit unggul sampai sekarang. Oleh karena itu, sejak dulu sampai sekarang, persawahan di Semende tetap dilakukan dengan pola 1 kali setahun.

Penggunaan bibit lokal dengan usia panjang, ternyata bukan tanpa alasan. Secara emic bahwa masyarakat melakukan itu terkait dengan adanya tanaman lain yang juga jadi tanaman penting di masyarakat, yaitu kopi. Selain bersawah, hampir semua masyarakat Semende Darat Tengah mengusahakan perkebunan kopi. Posisinya berada di sekitar perkampungan dan di lereng-lereng bukit. Melalui mekanisme sawah satu kali setahun, masyarakat mengaku memiliki waktu yang cukup untuk mengusahakan juga perkebunan kopi. Sebaliknya jika diganti dengan sawah dua kali setahun, dipastikan mereka tidak punya waktu cukup untuk mengolah kopi dan sawah.

Pola seperti ini memperlihatkan bahwa sawah dimaknai masyarakat bukan sematamata tanaman ekonomis, yang hasilnya menjadi patokan ekonomi keluarga. Sawah lebih identik sebagai bentuk ketahanan pangan masyarakat. Ini diperkuat dengan indikasi yang tampak bahwa pemanfaatan hasil sawah tidak untuk dijual. Padi hasil panen digunakan untuk tiga hal, yaitu bahan makanan pokok sekeluarga besar selama satu tahun, bahan bibit untuk musim tanam yang baru, dan cadangan apabila ada hajatan dalam keluarga. Sisa dari pembagian ini, barulah dijual (mengenai ini dapat dibandingkan hasil penelitian Iskandar, 2008 tentang komunitas Badui di Jawa Barat).

Kepemilikan sawah di Semende Darat Tengah terkait pula dengan struktur adat yang berlaku, yaitu adat Bemeraje Anak Belai atau lazim disebut dengan adat Tunggu Tubang. Adat ini menekankan pada pola hubungan kekerabatan yang erat yaitu hubungan antara Meraje (paman) dengan anak belai (keponakan)dan Tunggu Tubang (anak perempuan tertua dalam sebuah keluarga). Melalui ketentuan adat ini, setiap keluarga atau masyarakat Semende, di mana ia berada, pasti memiliki tunggu tubang. Apabila dalam sebuah keluarga tidak ada anak perempuan, maka akan dilakukan prosesi ambik anak (mengambil anak) untuk mengisi jabatan tunggu tubang (Rauf, 2002).

Inti dari sistem adatini yang berpengaruh kuat dalam pemanfaatan lahan sawah adalah sistem pewarisan dan posisi meraje. Setiap keluarga akan mewariskan harta keluarga kepada anak-anaknya. Pada adat Semende, pewarisan ini akan jatuh ke tangan anak perempuan tertua, yaitu tunggu tubang. Harta yang diwariskan tersebut adalah sawah, rumah, tebat (kolam ikan, jika ada) dan kebun kopi. Setiap tunggu tubang diwajibkan mengelola dan mengurus lahan tersebut, namun tidak bisa menganggapnya sebagai hak milik. Statusnya adalah hak guna pakai. Hasil dari lahan tersebut silahkan diambil tetapi tidak boleh dijual atau dialihfungsikan. Aktivitas ini akan senantiasa diawasi oleh meraje dari tunggu tubang tersebut.

Menjadi tunggu tubang, dalam konsep dasar adat Semende merupakan sebuah kebanggaan tersendiri karena ia dipastikan akan dapat sawah, rumah, dan kebun. Persyaratan standar hidup di pedesaan sudah dipenuhinya. Seorang tunggu tubang akan berkuasa dalam mengelola harta yang ada. Oleh karena itu, memiliki sawah dapat menjadi pertanda bahwa seseorang itu sudah menjadi tunggu tubang atau bakal diwariskan. Di sinilah tampak bahwa sawah juga memiliki makna simbolis sebagai simbol kekuasaan dan posisi sosial seseorang. Di zaman dulu, terutama era sebelum 1990-an, seorang pria yang memperistrikan seorang tunggu tubang, dianggap punya prestasi tersendiri karena tidak mudah untuk mendapatkannya.

Sawah dan tunggu tubang, menjadi satu ikatan yang tidak dapat dipisahkan. Sekaligus juga menunjukkan bahwa sistem pewarisan ala Semende ini, sangat khas dan mungkin 
hanya ada satu-satunya di Indonesia. Sedikit kesamaan dapat dilihat dari sistem adat di Minangkabau yang mengenal pola matrilineal (lihat Navis, 1984). Akan tetapi, di Semende punya kekhasan tersendiri, yaitu hak waris ada pada anak perempuan tertua, bukan semua anak perempuan, sebagaimana di Minangkabau. Kekhasan juga tampak dari item yang diwariskan yaitu sawah, rumah, kolam, dan kebun (harta tidak bergerak).

Oleh karena itu, sawah juga menjadi sebuah identitas bagi masyarakat Semende. Memiliki sawah berarti menjadi tunggu tubang atau punya keturunan yang siap jadi tunggu tubang. Dua hal ini adalah identitas penting bagi orang Semende, terbukti di Sumatera Selatan dikenal luas bahwa Semende adalah tunggu tubang dan sebaliknya. Bagi orang Semende, identitas ini jadi kebanggaan, terutama karena keunikan adat yang dimiliki dan hal itu diaplikasikan pula dalam sistem pertanian yang mereka lakukan.

Sawah sebagai simbol kesejahteraan, simbol kekuasaan, dan simbol identitas, telah dipahami masyarakat sejak zaman dulu dan merupakan sistem yang diwariskan sejak zaman nenek moyang mereka. Pengetahuan ini, diyakini bukan datang begitu saja, tetapi bagian dari komunikasi mereka dalam memaknai fenomena-fenomena lingkungan alam yang ada. Penjelasan secara etic pada penelitian, menunjukkan sisi komunikasi lingkungan yang dapat ditelaah secara rasional.

Melalui pendekatan komunikasi, terutama jika digunakan sudut pandang teori interaksionisme simbolik (Blummer, 1986), maka realitas yang terlihat adalah sebuah proses pemaknaan bersama dari masyarakat terhadap fenomena lingkungan alam yang ada. Sebagaimana juga dijelaskan oleh Mulyana (2002) bahwa komunikasi bersifat simbolik dan terjadi dalam ruang saling memaknai. Manusia selalu terikat dengan berbagai fenomena lingkungan yang kemudian membentuk perilakunya.

Hal ini dapat dilihat dari bagaimana masyarakat Semende memaknai sawah dalam tiga klasifikasi di atas. Pertama, simbol sawah sebagai tanaman non-ekonomis, tetapi dianggap lambang ketahanan pangan, diawali dengan asumsi bahwa daerah Semende yang dominan dengan perbukitan, tidak memungkinkan membangun lahan sawah dalam jumlah luas. Kemungkinan yang dapat dilakukan adalah membagibagi areal yang ada untuk semua warga, sehingga jumlahnya menjadi terbatas. Keterbatasan areal ini menyebabkan tidak dimungkinkannya terjadi penguasaan modal yang besar oleh satu orang. Harus ada kebersamaan yang mewadahi kebutuhan dan kepentingan semua orang. Prinsip masyarakat komunal berlaku di Semende. Hal ini dibandingkan dengan penelitian dari Lahajir (2001) tentang masyarakat peladang Dayak Tunjung Linggang di Kalimantan Tengah, yangjuga menganut sistem komunal.

Pembagian areal sawah yang hampir merata ini didasarkan atas pemahaman bersama masyarakat yang menyadari bahwa daerah Semende memang daerah bersama dan lahan terbatas. Adanya bukit-bukit, lembah, sumber air adalah simbol-simbol alam yang dimaknai masyarakat sebagai bentuk kepemilikan bersama.

Narasumber dalam penelitian ini, semuanya mengaku bahwa ini adalah warisan para nenek moyang, yang senantiasa diteruskan dan disampaikan kepada generasi-generasi berikutnya. Mereka memperoleh informasi ini dari pengetahuan orang yang lebih tua, berlanjut terus ke generasi seterusnya. Fakta-fakta dari penjelasan para orang tua ini bisa dilihat langsung dari fenomena alam yang ada, sehingga konfirmasi secara simbolik terhadap pengetahuan para orang tua dapat dilihat langsung.

Masyarakat Semende tidak menjual hasil sawah mereka, dapat dilihat sebagai pemaknaan simbolik terhadap fenomena alam. Struktur tanah di Semende yang berbukit-bukit dan subur, yaitu katagori tanah muda (andisol), menyebabkan tanahnya sangat cocok ditanam untuk jenis tanaman berudara dingin. Kopi menjadi pilihan utama. Apabila sawah dijadikan sebagai bentuk ketahanan pangan, maka kopi 
dijadikan sebagai barang komoditas. Inilah bentuk keseimbangan alam yang dilakukan masyarakat. Mereka memenuhi kebutuhan sekunder sehari-hari dari penjualan kopi, sementara untuk makanan pokok, dijamin oleh ketersediaan padi.

Dua jenis tanaman ini (padi dan kopi) kemudian menjadi dua jenis produk andalan yang dianggap harus ada di Semende karena disitulah letak keutuhan kehidupan yang mereka jalani. Hanya saja terdapat perbedaan bahwa padi adalah tanaman endemik mereka, dikenal sejak zaman nenek moyang, sementara kopi adalah komoditas yang dikenal belakangan, terutama sejak masuknya pengaruh kolonial Belanda yang mengharuskan menanam kopi. Indikasi sisi sejarah ini dilihat dari penamaan kopi dalam bahasa Semende yang disebut Kawe. Istilah ini dapat dibandingkan dengan sebutan Qahwee dalam bahasa Yaman sebagai daerah asal penyebaran kopi (Tanjung, 2011:133).

Oleh karena itu, padi menjadi komoditas lokal yang berkembang sesuai perjalanan masyarakat tersebut. Hal ini yang kemudian meneguhkan asumsi masyarakat bahwa padi yang mereka gunakan adalah produk lokal yang dianggap memang hanya cocok di Semende. Tampak jelas dari penggunaan bibit padi dengan pola panen 1 kali setahun. Alasan logisnya dapat dilihat bahwa kondisi cuaca di Semende yang memang berudara dingin, sinar matahari yang rendah, menyebabkan jenis padi lokal berbatang tinggi lebih cocok ditanam. Menurut penjelasan Pujiharti (2008) kondisi cuaca memang menentukan jenis padi yang akan ditanam karena ada beda karakteristik padi pendek dengan padi tinggi. Minimnya sinar matahari menyebabkan padi pendek sulit hidup karena kurang menyerap sinar matahari, sebaliknya padi tinggi mampu menyerap dengan baik.

Fenomena seperti ini menunjukkan bahwa nenek moyang orang Semende Darat Tengah sudah sangat menyadari dan memahami fenomena alam, dan pengetahuan itu diteruskan ke generasi berikutnya. Ini fakta penting yang menunjukkan bagaimana masyarakat berkomunikasi mengenai lingkungan alamnya. Mereka menangkap fenomena alam, kemudian memaknai, dan berperilaku sesuai fenomena yang ditangkap. Gambaran seperti ini dapat dikonfirmasikan dengan pendapat Blummer (1986) bahwa simbol-simbol bersifat sembarang, manusialah yang memaknainya. Tanaman padi yang ditempat lain dimaknai sebagai tanaman ekonomis, menjadi berbeda dengan makna masyarakat Semende Darat Tengah. Hal ini dapat dibandingkan dengan hasil penelitian Iskandar (2012) tentang pola pertanian di masyarakat Badui Dalam yang juga memberikan makna khusus terhadap tanaman padinya.

Fakta-fakta mengenai tanaman padi ini, begitu kuat diyakini masyarakat sehingga sampai sekarang tetap diberlakukan. Semua narasumber dalam penelitian ini, mengaku bahwa informasi mengenai mekanisme bertanam padi ini diperoleh dari generasi sebelumnya (kakek/nenek ataupun orang tua). Mekanisme penyebaran informasinya dilakukan secara intens dalam aktivitas keseharian. Bentuknya dengan mengajak ikut ke sawah, mengolah sawah, bercerita, ataupun menjelaskan soal cuaca, dan tata cara bersawah serta berkebun. Penjelasan mengenai berkebun kopi dan bersawah biasanya beriringan karena dua jenis tanaman ini saling berkaitan dalam aktivitas masyarakat.

Sementara itu, konstruksi masyarakat mengenai sawah sebagai simbol kekuasaan dan identitas, melekat dengan tatanan adat bemeraje anak belai yang berlaku di Semende. Pengetahuan mengenai adat ini berlaku sepanjang zaman dan tetap diteruskan sampai saat ini. Tunggu Tubang sebagai identitas dan juga sebagai simbol penguasaan lahan sawah, ditanamkan sejak dini kepada anakanak. Dalam obrolan di rumah tangga, sering didengar kata-kata bahwa komunitas mereka punya tunggu tubang. Sebagai contoh adalah ucapan yang menyebutkan bahwa "sawah kite ni ade sebidang, yang nak ngulahnye je lah ayuk kaba, tunggu tubang die tu" (sawah kita ini ada sebidang, yang akan mengolahnya 
adalah kakak perempuanmu, dia itu tunggu tubang).

Melalui mekanisme adat seperti di atas, maka lahan pertanian sawah di Semende cenderung tetap dan bahkan bertambah luas. Hal ini disebabkan oleh semakin banyaknya pembukaan areal sawah baru yang dilakukan oleh tunggu tubang yang baru pula. Di sinilah terlihat bahwa lahan sawah memiliki makna simbolik penting yaitu identitas bagi seorang warga Semende. Setiap warga Semende pasti memiliki tunggu tubang, dan seorang tunggu tubang pasti memiliki lahan pertanian, baik sawah ataupun kebun.

Penegasan mengenai kedudukan sawah ini, disebutkan oleh Minhar sebagai informan dalam penelitian ini dan sekaligus Ketua Adat Semende:

\begin{abstract}
"Yang namanya orang Semende, pasti punya tunggu tubang, dan harus punya sawah. Kalaupun tunggu tubang sudah pindah ke luar daerah, tapi sawahnya harus tetap ada. Sawah ini tidak boleh dijual, karena ini identitas kami, sekaligus untuk bahan makanan pokok sekeluarga besar. Karena itu, hasil sawah bukan untuk cari duit, tapi untuk hidup keluarga itulah. Kalau cari duit, ada di kebun kopi (Wawancara tanggal 10 Februari 2014).
\end{abstract}

Tampak bahwa keseharian masyarakat Semende Darat Tengah berada dalam tatanan adat dan itu terkait langsung dengan komoditas pertanian yang dilakukan. Semua ini merupakan siklus keseharian dan menjadi pola komunikasi tersendiri. Proses komunikasi lingkungan dalam memaknai sawah pada masyarakat Semende, dikatakan sebuah proses yang alamiah, terjadi dalam setting komunikasi yang terbuka, dan berlangsung sesuai tananan sosial masyarakat. Proses alamiah, artinya terjadi sesuai dengan ritmekehidupan mereka. Tidak ditemukan adanya mekanisme khusus yang bersifat formal, tetapi dilakukan sesuai ritme alam. Apabila orang tua mengatakan bahwa sawah harus ditanam dengan padi lokal dan dilakukan sekali setahun, maka ini dipahami secara langsung dengan mengerjakan sawah dan melihat orang lain melakukan itu. Hal inilah yang dikatakan dalam aksioma Jurin (2010) bahwa komunikasi adalah aktivitas manusia, dan pemahaman adalah sasaran komunikasi. Begitu pula dengan penegasan bahwa manusia hidup dengan bergantung pada alam.

Semua simbol-simbol alam, terutama yang berkaitan dengan sawah, dimaknai masyarakat sebagai fenomena tersendiri yang harus dipahami sebagai bentuk bertahan hidup. Cuaca yang dingin dimaknai sebagai simbol bahwa tidak mungkin menanam tanaman yang tidak tahan lama karena padi tinggi adalah pilihan. Aktivitas memahami alam inilah yang terlihat jelas sebagai peristiwa komunikasi lingkungan di masyarakat Semende.

Mengacu pada Blummer (1986), dimana tindakan simbolik akan menjadi ciri khas manusia, sekaligus membentuk jati dirinya, maka tampak jelas bahwa menjadikan tunggu tubang dan sawah sebagai identitas masyarakat Semende Darat Tengah adalah bentuk dari makna simbolik tersebut. Jati diri masyarakat Semende Darat Tengah terbentuk karena ada pemahaman bersama dalam memandang lingkungan alam, yaitu menjadikan sawah sebagai bentuk identitas yang melekat pada kelembagaan tunggu tubang.

Terbentuknya identitas atau jati diri ini bukanlah peristiwa yang berlangsung begitu saja, namun sebuah proses yang terjadi sepanjang waktu dan melibatkan struktur masyarakat Semende Darat Tengah. Proses ini berlangsung dalam setting (konteks) komunikasi keseharian masyarakat. Setting ini bisa ditemukan di dalam rumah, di sawah, di kebun, di lapangan olahraga, pada acara hajatan, di warung, di sekolah, maupun di masjid. Topik-topik mengenai sawah dan aturan-aturan yang harus digunakan, kerap muncul, dan menjadi sebuah perbincangan bersama. Sementara untuk pelaku komunikasinya yang terkait dengan struktur masyarakat Semende Darat Tengah terbagi atas kelompok orang tua (jeme tue), dewasa (batin/kerbay), remaja (bujang gadis), 
dan anak-anak (budak-budak). Komunikasi antara komponen inilah yang kemudian membentuk sebuah jati diri masyarakat Semende terkait dengan lahan sawah yang dimiliki.

Kelompok jeme tue memegang peran utama yang menjadi sumber informasi awal. Kelompok dewasa, juga menjadi sumber informasi, terutama pada kalangan di bawahnya. Sementara kelompok remaja cenderung mencari informasi dari atas (orang tua) dan sesama mereka. Khusus kelompok remaja ini, informasi juga mulai rutin diperoleh dari media teknologi informasi, seperti televisi, internet melalui telepon seluler, serta dari pendidikan formal yang mereka tempuh. Sementara bagi kelompok anak-anak, mereka mencari informasi dari semua kalangan di atasnya dengan sumber utama ada pada orang tua. Titik fokusnya tetap sama yaitu menjadikan sawah dalam pemaknaan bersama, sebagai simbol kesejahteraan, kekuasaan, dan identitas. Secara sederhana dapat dilihat dari bagan berikut ini.

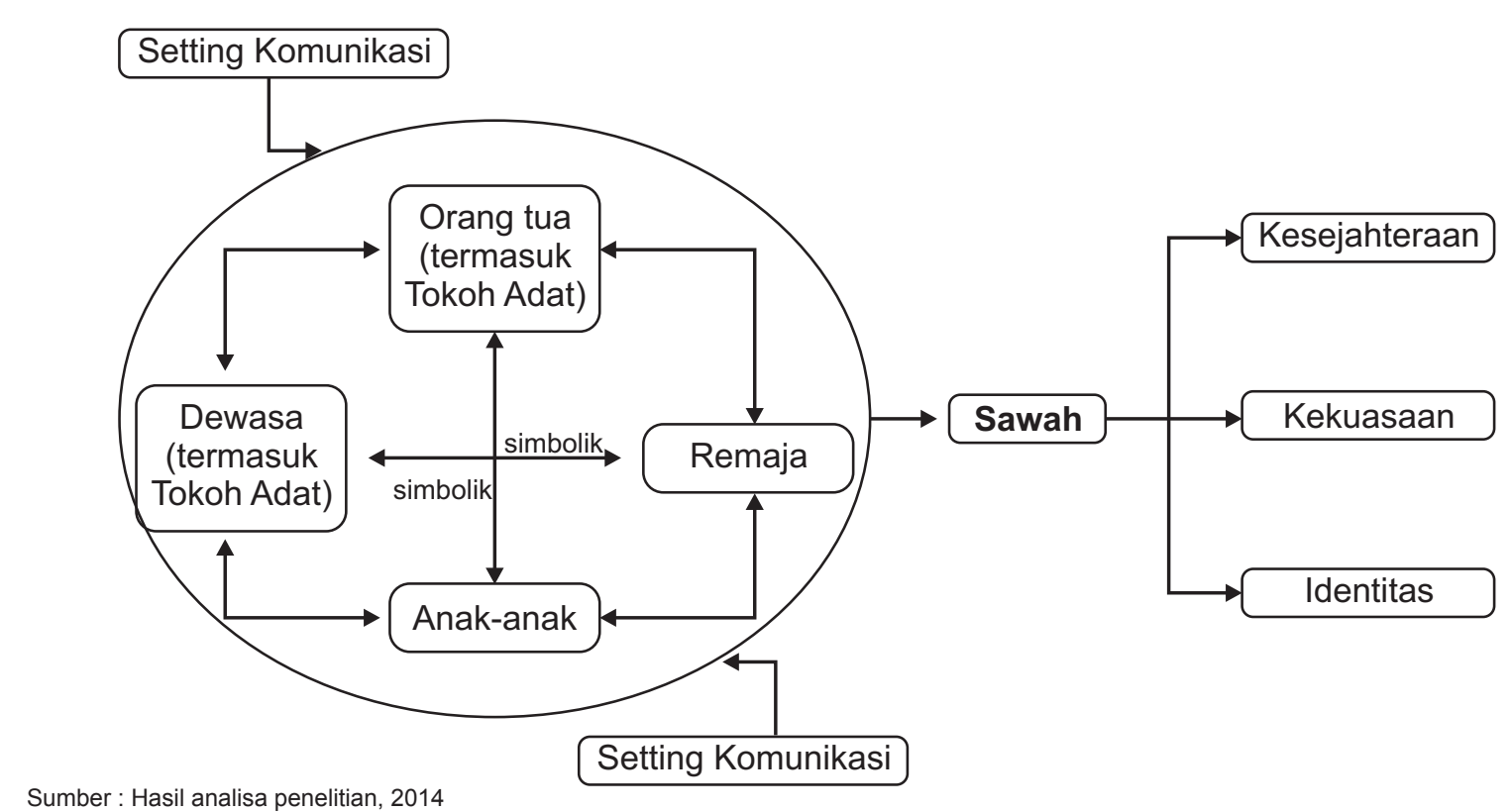

Sumber : Hasil analisa penelitian, 2014

Gambar 2

Proses Komunikasi dalam Pemaknaan terhadap Sawah

Tampak pada bagan di atas bahwa dalam struktur sosial masyarakat Semende, berada pada empat tingkatan, yaitu orang tua, dewasa, remaja, dan anak-anak. Mereka bukan pada posisi sejajar, tetapi bertingkat sesuai karakteristik masyarakat yang memang memberikan penghargaan pada orang yang lebih tua. Pada proses komunikasinya, selalu bersifat simbolik dalam memaknai fenomena alam, khususnya aktivitas bersawah. Aktivitas komunikasi berlangsung dalam setting tertentu yang bisa saja bervariasi, tetapi senantiasa bersifat alamiah dan berlangsung dalam suasana keseharian.
Pada bagan 1 menempatkan tokoh adat ada dalam kelompok orang tua dan dewasa. Hal ini disebabkan oleh tokoh yang dikenal di masyarakat Semende Darat Tengah, terutama yang punya kaitan dengan pemaknaan sawah adalah kalangan tokoh adat. Ini terkait dengan sistem adat tunggu tubang yang berlaku. Tokoh adat yang paling utama adalah Meraje (paman, saudara lakilaki tertua dari tunggu tubang) dan Jenang Meraje (kakek). Dua kelompok ini menjadi penentu dalam pelaksanaan adat tunggu tubang karena fungsinya melekat sebagai pengawas dan pembimbing terhadap 
seluruh keponakannya. Struktur adat Semende, semua orang pasti memiliki Meraje dan Jenang Meraje. Mereka akan diawasi dan seringkali diingatkan oleh kedua lembaga tersebut agar selalu mengusahakan sawah sesuai tradisi yang berlaku. Tunggu Tubang sendiri sebagai lembaga yang memiliki otoritas besar dalam pengusahaan sawah, berada dalam pengawasan Meraje.

Meraje ataupun Jenang Meraje adalah posisi dalam struktur adat. Pada praktiknya mereka dapat berada dalam kelompok usia dewasa (di bawah 50 tahun), ataupun masuk dalam kalangan orang tua (di atas 60 tahun). Hasil penelitian ini menunjukkan bahwa pengaruh besar Meraje dan Jenang Meraje adalah terhadap keluarganya, bukan pada seluruh masyarakat karena tiap masyarakat Semende pasti punya Meraje masing-masing. Oleh karena itu, dalam proses komunikasi terhadap pemaknaan sawah, peran para tokoh ini membaur dalam kelompok dewasa dan orang tua, yang melakukan proses internalisasi terhadap anggota keluarganya masing-masing.

Di antara masing-masing kelompok masyarakat juga terjadi proses belajar dan mengajari, terutama dari kelompok yang tua kepada yang muda. Pengajaran ini dikaitkan dengan fenonema alam dapat diidentikan juga dengan berlangsung proses pendidikan lingkungan, sekaligus juga interpretasi lingkungan (Jurin, 2010). Pada akhirnya ini menjadi sebuah bentuk komunikasi lingkungan yang berlangsung dalam sebuah tatanan masyarakat mengenai fenomena persawahan yang dilakukan.

\section{SIMPULAN}

Penelitian ini berhasil menarik benang merah bahwa pemaknaan masyarakat terhadap fenomena lingkungan, terutama kegiatan bersawah, menghasilkan tiga makna simbolik dari sawah, yaitu sebagai simbol kesejahteraan, simbol kekuasaan, dan simbol identitas. Masing-masing pemaknaan ini memiliki kontribusi besar terhadap tatanan kehidupan masyarakat yang sampai saat ini tetap bisa hidup berdampingan dengan lingkungan alam. Mekanisme bersawah yang dilakukan warga dengan pola satu kali setahun adalah bentuk pemahaman terhadap fenomena lingkungan, keseimbangan ekologis dan sistem sosial, alih-alih bukan bentuk ketertinggalan atau keengganan untuk berubah. Semua hal itu terjadi dalam sebuah aktivitas proses komunikasi lingkungan yang sesuai dengan struktur sosial masyarakat, dengan berlangsungnya mekanisme simbolik yang berlangsung secara rutin dan alamiah.

Berdasarkan hasil penelitian ini, maka disarankan agar bentuk-bentuk pemaknaan lokal masyarakat harus dipahami sebagai sebuah mekanisme komunikasi lingkungan yang adaptif. Sangat disarankan agar kebijakan-kebijakan modernisasi pertanian, memperhitungkan pengetahuan lokal yang sudah dikenal masyarakat, dan tidak justru kemudian bertolakbelakang dengan karakteristik lingkungan alam masyarakat setempat. Harus ada pula upaya memperkuat kelembagaan lokal, karena ini akan berpengaruh terhadap tatanan sosial budaya dan ekosistem di sebuah komunitas. Kelembagaan lokal yang utama adalah lembaga adat tunggu tubang yang ada di setiap keluarga besar. Upaya memperkuatnya dapat dengan dorongan dari dalam masyarakat (internal) ataupun dari luar (eksternal). Secara internal, ini harus dilakukan masyarakat sendiri, terutama kalangan meraje dan tunggu tubang dengan senantiasa mengingatkan dan memberi arahan kepada seluruh anggota keluarganya bahwa lembaga lokal yang ada merupakan identitas yang tidak dapat dihilangkan. Meraje artinya juga "memaksa" anggota keluarganya, yang walaupun sudah berdomisili di luar daerah, untuk menjaga sawah dan tanah yang ada di Semende. Dari kalangan eksternal, harus didorong dengan kebijakan pemerintah, di mana setiap program pembangunan yang akan diterapkan harus dengan memberdayakan/ melibatkan kelembagaanlokalyangada, yang menunjukkan "pengakuan" dari pemerintah terhadap institusi lokal yang ada. Hal ini penting, karena akan semakin mengukuhkan 
posisi meraje dan tunggu tubang sebagai institusi utama dalam aktivitas pertanian di Semende Darat Tengah.

\section{DAFTAR PUSTAKA}

Blumer, H. 1986. Symbolic Interactionism, Perspective and Methode, University of California Press, Los Angeles, California.

Boomgard, P. 2003. In the Shadow of Rice, Roots and Tubbers on Indonesian History, 1500-1950, Agricultural History Volume 77, 582-610.

Cox, R. 2010. Environment Communication and Public Sphere, Second Edition, Sage Publications, USA.

Conklin, H. 1963. The Study of Shifting Cultivation, Washington DC.

Flor, A. G. 2004. Environmental Communication: Principles, Approaches and Strategies of Communication, Applied to Environmental Management, University of the Philippines, Philippines.

Iskandar, J. 2012. Ekologi Perladangan Orang Baduy, Pengelolaan Hutan Berbasis Adat secara Berkelanjutan, Penerbit Alumni, Bandung.

Jurin, R., Donny R., Jeff D. 2010. Environmental Communications, Skill and Principles for Natural Resources Managers, Scientist, and Engineer, Springer Doerdrecht Heidelberg, Newyork, London.

Lahajir. 2001. Etnoekologi Perladangan Orang Dayak Tunjung Linggang, Galang Press, Yogyakarta.

Marzali, A. 2012. Antropologi dan Kebijakan Publik, Kencana Prenada Media Group, Jakarta.
Mead. George H. 1967. Mind, Self, and Society, The University of Chicago Press, London.

Mulyana, De. 2002. Ilmu Komunikasi: suatu Pengantar. Rosda Karya, Bandung.

Navis, AA. 1984. Alam Takambang Jadi Guru, Grafitti Press, Jakarta.

Panuju, DR., Kei Mizuno and Bambang $\mathrm{H}$ Trisasongko. 2013.The Dynamics of Rice Production in Indonesia 19612009, Journal of the Saudi Society of Agricultural Science, King Saud University, Volume 12, 27-37.

Pujiharti, Yulia, Junita Barus dan Bambang Wijayanto. 2008. Teknologi Budidaya Padi. BPPTP, Bogor.

Rambo, A Terry dan Percy Sajise (ed.). 1984. An Introduction to Human Ecology Research on Agricultural Systems in Southeast Asia, University of the Philippines, University Publication Program, College, Laguna, Philippines.

Rauf, T.A. 2002. Jagat Besemah Lebar Semende Panjang, Pustaka Dzumirroh, Yayasan Nurqadim, Palembang.

Santun, Dedi Irwanto, Murni dan Supriyanto. 2010. Iliran dan Uluan, Dinamika dan Dikotomi Sejarah Palembang, Eja Publisher, Yogyakarta.

Soemarwoto, O. 2008. Ekologi, Lingkungan Hidup dan Pembangunan, Penerbit Djambatan, Jakarta.

Tanjung, F. 2011. Dairi dalam Kilatan Sejarah, Penerbit Perdana Publishing, Medan. 